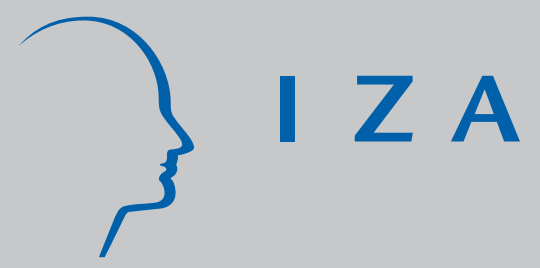

IZA DP No. 67

Behavioral Effects of Probation Periods: An Analysis of Worker Absenteeism

Regina T. Riphahn

Anja Thalmaier

October 1999 


\title{
Behavioral Effects of Probation Periods: An Analysis of Worker Absenteeism
}

\author{
Regina T. Riphahn \\ University of Munich, \\ CEPR, London and IZA, Bonn
}

\section{Anja Thalmaier}

$I Z A$, Bonn

\author{
Discussion Paper No. 67 \\ October 1999
}

\author{
IZA \\ P.O. Box 7240 \\ D-53072 Bonn \\ Germany \\ Tel.: +49-228-3894-0 \\ Fax: +49-228-3894-210 \\ Email: iza@iza.org
}

This Discussion Paper is issued within the framework of IZA's research areas Mobility and Flexibility of Labor Markets and The Welfare State and Labor Markets. Any opinions expressed here are those of the author(s) and not those of the institute. Research disseminated by IZA may include views on policy, but the institute itself takes no institutional policy positions.

The Institute for the Study of Labor (IZA) in Bonn is a local and virtual international research center and a place of communication between science, politics and business. IZA is an independent, nonprofit limited liability company (Gesellschaft mit beschränkter Haftung) supported by the Deutsche Post AG. The center is associated with the University of Bonn and offers a stimulating research environment through its research networks, research support, and visitors and doctoral programs. IZA engages in (i) original and internationally competitive research in all fields of labor economics, (ii) development of policy concepts, and (iii) dissemination of research results and concepts to the interested public. The current research program deals with (1) mobility and flexibility of labor markets, (2) internationalization of labor markets and European integration, (3) the welfare state and labor markets, (4) labor markets in transition, (5) the future of work, (6) project evaluation and (7) general labor economics.

IZA Discussion Papers often represent preliminary work and are circulated to encourage discussion. Citation of such a paper should account for its provisional character. 


\section{ABSTRACT}

\section{Behavioral Effects of Probation Periods: An Analysis of Worker Absenteeism*}

The theoretical probation literature shows that individuals have incentives to mimick "good workers" during periods of employment probation. This study empirically tests at the example of absence behavior, whether such behavioral responses to the incentives of probation periods exist. We find significant responses of white collar employees and public sector workers to probation periods: Once individuals enter into regular employment and employment probation is completed, the probability of work absences takes discrete jumps and is significantly above previous levels.

JEL Classification: J22, D80

Keywords: Probation, absenteeism

Regina T. Riphahn

University of Munich

Ludwigstr. 28 RG

80539 Munich

Germany

Tel: +498921802128

Fax: +498933 6392

email: Regina.Riphahn@selapo.vwl.uni-muenchen.de

\footnotetext{
Helpfuls comments of the participants of the 1999 European Summer Symposium in Labour Economics at Ammersee, of the 1999 workshop on "Employment Inequality and Growth" in Zurich, and of Edward Bird on a prior version of this paper are gratefully acknowledged
} 


\section{Introduction}

In recent years probation periods in employment contracts have received increasing attention in the labor economics literature. Probation periods are fixed-length monitoring and testing periods imposed on newly hired employees (Loh 1994a). The literature discusses rationales for the existence of probation periods as well as the Pareto optimality of certain types and lengths of probation contracts. ${ }^{1}$ A result of these studies is that probation periods function as worker screening devices. The theoretical analyses typically assume that bad or poorly motivated workers with private information on these characteristics have an incentive to mimick good workers during probation periods.

While the interpretation of probation periods as screening devices has been subjected to empirical tests and found empirical support by Loh (1994b), so far there is no empirical study which looks at whether workers indeed adjust their behavior during probation periods. Therefore this paper investigates whether workers respond to the incentives inherent in the nature of probation periods and mimick good workers in this time. Our indicator for behavioral adjustment is work absenteeism and consequently we ask whether workers reduce absence rates during probation periods. The propensity to mimick good workers during the probation period can be identified as the degree to which absenteeism increases once the end of the probation period is reached. If absence rates step up markedly after the end of employment probation, this supports the hypothesis of worker responses to probation incentives and indicates the degree to which the provision of relative employment security induces absenteeism.

The issue of worker absenteeism continues to employ policy debates in western welfare states, as significant expenditures result e.g. from sick-leave provisions. In Germany sick-leave costs about the same as the social assistance program and represents the sixth most expensive social policy program (cf. STBA 1998). Therefore it is of interest to investigate and quantify employee moral hazard behavior, here at the example of workers' responses to probation periods. Besides their immediate policy relevance, the findings of this study provide an empirical basis for the theoretical literature on optimal employment contracts and on the effectiveness of probation periods as employee screening devices.

\footnotetext{
${ }^{1}$ See e.g. Sadanand et al. (1989), Bull and Tedeschi (1989), Weiss and Wang (1990), or Wang and Weiss (1998) for theoretical, and Loh (1994a, 1994b) for empirical contributions.
} 
To further motivate the subsequent analysis, Section 2 surveys the relevant literature. Since we apply German data, Section 3 briefly describes the German institutional background on probation and absenteeism. The data and methodological approach are introduced in Section 4. Section 5 discusses the results and a conclusion rounds up the paper.

\section{Literature}

Two strands of literature are relevant to our analysis: One provides a theoretical discussion of the institution of employment probation and the other empirically investigates worker absenteeism and its determinants.

In the framework of asymmetric information on worker productivity, the theoretical probation literature compares the implications of probationary versus recontracting employment schemes (Sadanand et al. 1989), and investigates the features of optimal probation contracts. Bull and Tedeschi (1989) and Weiss and Wang (1990) study determinants of the optimal length of probation periods and of the optimal firm response to worker failure during probation (for a survey see also Loh 1994b). Recently Wang and Weiss (1998) provided an analysis of probation and wage-tenure profiles. They showed that a sorting explanation of probation is consistent with stylized facts such as that jobs with probation periods have lower starting wages, but higher wage increases than non-probationary jobs. This implication is also derived, and empirically confirmed in Loh (1994b). Using a cross-section of 1981 data on the last hires of 1,881 firms, the author finds evidence for self-selection into probationary employment and a significant positive correlation between high wage growth and the propensity to chose a probationary job. Also, Loh (1994b) confirms that at least among older workers the probability to quit a job is lower among those who passed probation periods.

The recent absenteeism literature concentrates on a bundle of possible determinants, such as remuneration schemes (Johansson and Palme 1996, Barmby et al. 1995), firm size (Barmby and Stephan 1996), or gender (Vistnes 1997). Given the variance in data, methods, and research questions there is little consensus on the central determinants of absenteeism. The majority of studies finds negative correlations between income and absenteeism as well as higher absenteeism in large firms, for women, and for young individuals.

\section{German Institutional Framework: Employment Probation and Sick-leave}

Our empirical test of employee moral hazard behavior is based on a provision in German labor 
law which indirectly regulates probation periods: During the period of the first six months on a new job, the detailed and binding laws governing layoff do not hold. These regulations otherwise restrict the situations in which layoff is legally possible as well as the length of the mandatory notice period. During the six month period employees can quit and be fired without long notice periods, and, more importantly, without fulfilling the requirement of "proper cause." This requirement mandates that employees can be laid off only for reasons connected to their person or behavior, such that e.g. changes in business conditions are an insufficient justification for layoff. German labor courts have been very restrictive in accepting "proper cause" (Schaub 1997a). Therefore, the first six tenure months are an opportunity for employers to sort their workers, as it is only then that they can respond directly to unsatisfactory employee performance.

While employment probation is not directly mandated by law, it is a common work agreement and typically precedes regular employment contracts. Probation agreements allow both employers and employees to find out whether the match of the worker to the job is suitable, before committing to the binding rules of a formal employment relationship (for details see Schaub 1997b, or Bruse 1991). With no legal stipulations governing probation periods, this type of labor contract has been regulated in numerous agreements between unions and employers. The stipulations on probation duration generally differ for blue and white collar workers and can vary across industries and regions. While probation periods of one and three months exist for blue collar workers, the typical duration for white collar workers in the public and private sector is six months. The probation period is followed either by layoff or by a regular employment contract. The terms of subsequent employment contracts are frequently determined based on worker performance during the probation period.

Employment probation in Germany differs in four dimensions from probation in the United States, which is described in the existing literature: First, in Germany all employees are covered by layoff protection regulations. Thus Loh's argument (1994b, p.485) that "Because firms are largely free to fire workers for cause at any point in the employment relationship, it is not obvious why they need to institute the costly process of employment probation to identify poor workers." does not apply to Germany. Second, since layoff protection commences for all workers only after the first six months of employment, higher wages for workers in probationary jobs (to compensate the higher layoff risk, as 
implied for the United States) are not plausible in the German case. ${ }^{2}$ Third, probation in Germany is independent of the unionization status of a firm (cf. Loh 1994a). Fourth and finally, bilateral contracts between unions and employer associations often stipulate the lengths of bargained probation periods, such that the firm is not free to determine a worker-specific duration.

An aspect relevant for absenteeism -- though independent of probation regulations -- is the institutional design of sick-leave benefits: Individuals who miss work due to health reasons receive sick-leave benefits during probation as well as regular employment. Since 1970 blue and white collar workers can claim their full earnings for the first six weeks of any disease or illness from their employer without waiting periods. Only after employees have missed work for two days they are required to present a doctor's statement to the employer, which indicates that a health problem exists and for how long they are expected to be unable to work. If employees are unable to work after the six week period, 80 percent of their earnings will then be provided by the health insurance for up to another 78 weeks (BMA 1995). The regulations covering the first six weeks of any health problem were changed for the time between 1996 and 1998, when workers had statutory claims to only 80 percent of last earnings. However, even then unions negotiated the continuation of full coverage for almost all industries.

\section{Description of the Data and Empirical Approach}

\section{Sample and Core Variables}

The analysis is based on fourteen annual waves of data from the German Socioeconomic Panel (GSOEP, 1984! 1997). The GSOEP provides rich information on a representative sample of native and an oversample of foreign residents in Germany and it is the only microlevel panel dataset available to analyze probation and absenteeism in Germany. We consider full- and parttime employees and drop the self-employed, those in minor or irregular employment, as well as individuals in apprenticeship programs from the sample, because these persons are differently affected by probation periods.

The dependent variable is a dichotomous indicator which describes whether a worker has missed at least one day of work in a given calendar year. Our analysis relies on identifying differences in the propensity to miss work based on tenure months. Unfortunately the questionnaire does not

${ }^{2}$ While the layoff protection regulation is mandatory only after the first six months of employment, in cases where a probation period of less than six months is agreed upon - as it may be the case for blue collar workers - legal opinion is divided on whether the layoff protection commences already after the third month. 
provide an assignment of the time of absence to a specific calendar month. Since we have to connect the observed probability of absenteeism to a workers' tenure, we have to disregard observations on those individuals, who changed their employment during the course of the year: If individuals changed their job (with or without employment interruptions) in an ongoing calendar year, we do not know during which employment relationship an absence occurred. Due to the thus required censoring of observations in new employment relationships, we drop 1,025 annual observations, which may reenter the sample in later periods. Generally, all observations of job starters are considered in the analysis independent of the length of the subsequent employment relationship.

The most important explanatory variable in our analysis is the tenure measure itself. The GSOEP does not ask individuals directly whether and for how long they went through employment probation on a new job. Therefore our approach is to investigate the absenteeism behavior of all job starters, and to distinguish between blue and white collar workers, where white collar workers typically face a probation period of six months, and blue collar workers in some cases may have probation periods of one or three months only. To identify probation effects we relie on the tenure measure: Those workers, who have a tenure of more than six months, are considered to have completed their employment probation, while those who at the end of the calendar year accumulated a tenure of less than six months, are considered to still be in probationary employment. We hypothesize that the probability of absence takes a discrete step up after the end of probation. The GSOEP data allow an exact calculation of tenure months.

The tenure based identification of probation effects bears two consequences, the first which we label exposure effect: If individuals had a fixed probability of absenteeism per period, then absenteeism rates were lower among those who were employed for only short periods of the year. The longer a person's exposure to the risk of absenteeism, the higher the chances that at least one day of work has been missed. We have to separate reduced absenteeism due to the incentive effects of probation from that due to short exposure periods. Figure 1 depicts the situation. If annual absence rates are fixed e.g. at 50 percent, then the exposure effect leads to a linear increase in the observed probability of absenteeism up to the first full year of tenure, when it reaches 50 percent. This is represented by the straight line. If individuals on employment probation miss work less often, we would expect a lower rate of absenteeism for the time until the end of probation at tenure month six when the dashed line joins the straight line.

The second consequence of our tenure based probation measure relates to seasonality 
effects. Because the absenteeism measure is based on the calendar year, all observed employments with e.g. a tenure of two (eight) months began in November (May) and the tenure indicator might pick up season effects. If it were the case that health problems occur mostly in the first quarter of the year, we would notice spuriously heightened absenteeism for those with 10 through 12 months of tenure by the end of the year, and would misinterpret low absence rates at short tenure periods as responses to probation incentives. Unfortunately it is not possible to correct for this problem with our data. Barmby et al. (1997) construct monthly absence rates based on British data and find that the propensity to miss work is highest in the first quarter, low from April through September and high again beginning in October. Available information for Germany is summarized in Figure 2 and confirms this pattern. Since both halves of the year contain periods of high and low absence rates, and since there is no drop in sickness probabilities between June and July, seasonality is unlikely to bias our results on the absenteeism effects of tenure. ${ }^{3}$

\section{How do We Measure the Effect of Probation Periods?}

We measure the effect of probation periods by estimating the correlation between tenure and the probability of absence using a probit estimator. In order to interpret the estimation results we predict the probability of absenteeism for different tenures, and evaluate the increase in probability of absence with increasing months of tenure. If probation periods indeed cause a reduction in absenteeism we expect to find a steeper increase in the probability of absenteeism between the last month on probation and the first month afterwards (typically between tenure months six and seven) than between any other two months of tenure.

In order to test the robustness of our results we apply alternative estimation approaches to a variety of samples. The first set of estimations uses only observations with an observed tenure of up to one year, which suffices to investigate probation period effects. Step one is then to estimate the coefficients for a linear tenure month indicator, and a spline which interacts the observed tenure month variable with an indicator for being within the first six months of an employment relationship. Since this specification may force probation effects simply by its parameterization, we then "nonparametrically" estimate the coefficients of tenure month indicators in the probit model in step two of the analysis. We

${ }^{3}$ In contrast to the results of micro-data analyses the macro-data show higher absenteeism rates for men than for women. This is most likely due to the selection of men into more accident-prone occupations (for similar results see also Schnabel and Stephan 1993). 
perform estimations for subsamples stratified by blue versus white collar characteristics, by public sector employment, and by sex. In step three we test whether the results are robust to the control for other determinants of absenteeism, and consider a set of explanatory variables. Finally, it is possible that individual-specific unobserved effects such as genetic frailty or willingness to work when ill systematically affect absence probabilities. In order to control for these effects we consider the full sample of employee-year observations, independent of whether the employment is observed in the first year of tenure. This provides multiple observations per employment relationship and permits a random effects panel estimation in step four of our analysis.

The variables considered in steps three and four of the analysis are chosen based on the established absenteeism literature. We control for demographic variables such as age, sex, nationality, and marital status. Since individual health status may strongly influence absence probabilities we consider a person's health satisfaction and handicap status. As characteristics of the employment relationship we control for whether the employment is in the public sector, for the number of contracted working hours per week, blue vs. white collar status and whether the firm has fewer than 20 employees. Following efficiency wage theories labor earnings and outside employment options may be important determinants of shirking and absenteeism: In order to control for the effects of earnings and to avoid endogeneity problems we considered individual years of schooling as a measure of human capital. Outside employment options are reflected in the annual unemployment rate of workers' federal states. ${ }^{4}$ For descriptive statistics on the sample of observations with tenure up to one year see Table 1. Table 2 describes the outcome variable by completed tenure month and subsample. While the overall number of observations (799) seems sufficient for a reliable analysis, the cell sizes in some of the separately analysed subsamples are rather small. Therefore we utilize indicator variables which summarize the joint effect of two months of completed tenure on the probability of absence.

\section{Results}

The estimation results for steps one and two of the analysis are presented in Table 3 . In a first attempt to determine the degree to which the probability of absence is reduced during the time of employment probation, we specified a model along the stylized depiction in Figure 1: It controls for a

\footnotetext{
${ }^{4}$ In preliminary estimations a richer specification of firm size indicators and human capital measures were considered. However, these variables did not add to the explanatory power of the model and were neither individually nor jointly statistically significant. Therefore they are omitted in the final specification.
} 
linear tenure months effect, an indicator for the first six months of tenure ("probation") and an interaction of the two measures. Column (1) of Table 3 presents the estimation results for the full sample. Though individually insignificant, the three estimated coefficients are jointly significant at the one percent level.

The simulation results in the bottom panel of Table 3 indicate the predicted absence probability at different months of tenure. When comparing the probability over increasing tenure months we find indeed a much steeper increase between tenure months 5/6 and 7/8 (from 33.1 to 44.9 percent) than between any other two predicted probabilities. This is a first indication that there may indeed be an increase in absence rates after the end of the probation period.

However, we are sceptical of these results, as they may be influenced by the definition of the "probation" variable at exactly 6 months. Instead of discussing these first step results in detail, we therefore prefer to review the evidence generated by step two of our analysis. Here we specify the model of absence probabilities as a function of five tenure month indicator variables, where the indicator for eleven and twelve months of tenure serves as reference group. The estimation results are presented in columns (2) through (7) in Table 3, separately for the full sample, for blue and white collar samples by gender, and finally for white collar employees in the public sector. These subsamples are considered separately, because probation periods are regulated separately for blue collar, white collar, and public sector employees. While cases of one or three months probation periods are known for blue collar workers, white collar workers typically are subject to six months probation, and there is strong evidence that public sector white collar employees undergo a probation of exactly six months (Bruse 1991). Due to the small number of cases this subsample is not divided by gender.

A likelihood ratio test yields that the tenure specifications are jointly significant in the absence models for all but the male subsamples (columns 2 and 4). For the full sample we find significantly lower absence probabilities for tenure months 1 through 6 than for the reference group, as expected based on Figure 1. For male employees some coefficients of short tenure months are negative and significant. In the white collar specifications hardly any tenure months effect is statistically significant. Results are reversed for the public sector sample: Here higher tenure months yield statistically significant positive effects on the probability of absence.

We took two paths to evaluate the evidence on whether absence probabilities increase particularly strongly after the end of the probation period, i.e. between tenure months six and seven: First we tested whether the difference between the estimated coefficients for tenure months $5 / 6$ and for 
tenure months $7 / 8$ was especially large. If this were the case it could indicate that the effect of reaching tenure month 7 has the expected positive effect on the absence probability. We tested whether this difference was larger than either the difference between the coefficients for tenure months $5 / 6$ and $3 / 4$ or between the coefficients for tenure months $7 / 8$ and 9/10. For the full sample, blue collar, and female white collar workers the hypothesis of an unusual jump in the tenure months effect was rejected. However, for the samples of all white collar employees (estimation results not presented in Table 3), of male white collar employees (column 5), and for the sample of public sector employees (column 7) we found a significantly larger difference between the coefficient pairs for tenure months $5 / 6$ and months $7 / 8$ than between the neighboring coefficient pairs. ${ }^{5}$ For these subsamples we find evidence in support of the behavioral effects of probation periods.

The second path chosen to evaluate the available evidence was to apply the estimation results to simulate the probability of absence separately for each possible tenure month outcome. The predicted probabilities are presented in the bottom panel of Table 3. The bootstrapped standard errors of the predicted probabilities yield that with two exceptions all predicted probabilities are significantly different from zero. When comparing the probability of absence predicted at tenure months $5 / 6$ with the subsequent outcome we find indeed marked increases for all but the male blue collar sample. These predicted probabilities are plotted in Figure 3 for the various samples with 90 percent pointwise confidence bands. With the exception of the male blue collar sample these results confirm steep increases in absence probabilities after months $5 / 6$ for all subsamples. For public sector employees this increase is statistically significant at the ten percent level.

A surprising feature in the figures for white collar men (Figure 3.4) and for public sector employees (Figure 3.6) is that the absence probability peaks in tenure months 3 and 4 and declines thereafter. This might be coincidence or due to outlying observations in the category of 3 and 4 tenure months. Alternatively, the likelihood of absence might be sensitive to the upcoming evaluation at the end of the probation period. Another feature of the graphs which cannot be explained is the decline in absence probabilities at tenure months 11 and 12 . This unexpected situation was already apparent in the descriptive statistics of Table 2.

5 The hypothesis that the coefficient differences (tenure 5/6 ! tenure 3/4) equals that of (tenure 7/8 ! tenure 5/6) was rejected at the five percent level for the sample of all white collar workers and for public sector workers, and at the 10 percent significance level for male white collar workers. For the public sector wokers the hypothesis that the coefficient differences (tenure $7 / 8$ ! tenure 5/6) equals that of (tenure 9/10 ! tenure 7/8) was rejected at the ten percent significance level as well. 
The findings so far indicate that there is statistical evidence in favor of significant jumps in the probability of absence after the end of probation periods for the subsamples of public sector employees and white collar workers. While the simulations at the full sample suggest steep increases in absence probabilities after the end of the probation period, these findings are not statistically significant.

In order to test the robustness of our results, we added explanatory variables to the specification and redid the analysis of step two for each of the subsamples. The estimation results for the additional explanatory variables are presented for the full sample in the first columns of Table 4. Table 5 shows the coefficient and simulation results which were obtained just as those in Table 3, only this time additionally controlling for explanatory variables.

For the full sample of observations with tenure up to one year, Table 4 (column labelled "Step 3") presents a number of statistically significant determinants of absence behavior. Advanced age seems to be correlated with a significantly decreasing absence probability, a finding which corresponds to the results in the absenteeism literature (Johansson and Palme 1996). The age coefficients are individually and jointly (test statistic at the bottom of Table 4) significant. Among the demographic variables only nationality yields an additional significant impact: Non-Germans have lower absence probabilities. As expected each of the health indicators, i.e. handicap status and low health satisfaction significantly increase the probability of work absence in the first year of tenure. Among the variables describing the employment relationship only contracted work time affects absence significantly. While public sector employees appear to have a higher absence probability, the difference is not significant. In our limited sample we also do not find the common effects of firm size and human capital on absence behavior (e.g. Barmby and Stephan 1996, see footnote 4). Finally, as predicted by efficiency wage theory, absence probabilities are lower in states with high unemployment. These explanatory variables are controlled for in each of the models presented in Table 5. However, to save space we discuss only the tenure effects in these estimations.

After comparing the results in Table 5 with those obtained without controls for additional explanatory variables and presented in Table 3 , the overall conclusion is that the results did not change in important ways and are robust to the consideration of additional variables. This holds for the significance patterns of the tenure variables, as well as for the size and statistical significance of the predicted absence probabilities (bottom panel of Table 5). A comparison of the predicted probabilities of absence by tenure month in the bottom panel of Table 5 confirms that the increase in absence 
probabilities after tenure month 6 is marked in almost all subsamples.

Again we tested whether the difference in the coefficients between tenure months 5/6 and tenure months 7/8 exceeded that of other 'surrounding coefficient pairs.' As above, this hypothesis could not be rejected for the samples of all white collar workers (results not presented in Table 5) and the sample of public sector employees. ${ }^{6}$ Therefore we can conclude that the consideration of explanatory variables does not affect our main finding of significant probation effects for white collar workers and public sector employees.

Our fourth and final analysis step was to reestimate our models controlling for the effects of unobserved individual-specific heterogeneities in a random effects panel probit model. Since this requires more than one outcome per individual we lifted the restriction that our sample contains only observations with a tenure of at most one year. In the random effect probit estimations we consider all 30,028 available person-year observations. The model specification follows that discussed above, only adding tenure and its square to control for the tenure of individuals who have been in the same job for longer than one year.

As an example for all estimations, the last columns of Table 4 (labelled "Step 4") present the estimation results for the full sample. The results for all subsamples yielded statistically significant correlations in error terms ("Rho"). The effects of the independent variables roughly confirm those obtained with the smaller sample in step 3 of the analysis. The results on the tenure effects during the first employment year are presented by subsample in Table 6 . The evidence confirms the large increases in absence probabilities after the tenure month six, which we encountered already in prior analysis steps. Again there is a significant difference in the increase of the coefficient values between tenure months $5 / 6$ and $7 / 8$ for the public sector sample.

As a final indication of the robustness of our findings we plot the simulation results derived in steps two through four of the analysis for three subsamples in Figure 4. Particularly for female white collar and public sector workers the similarity in predicted absence probabilities is striking. The pattern clearly deviates from that generated by a simple exposure effect.

\section{Conclusions}

6 The hypothesis that the coefficient differences (tenure 5/6 ! tenure 3/4) equals that of (tenure 7/8 ! tenure 5/6) was rejected at the ten percent level for the sample of all white collar workers and at the 5 percent level for public sector workers. 
This study adds to the literature on probation employment contracts by testing a standard assumption underlying theoretical analyses: It investigates whether workers respond to the incentives inherent in probation periods. Probation periods typically precede regular employment contracts and are commonly interpreted as a screening device for employers. During probation periods employers learn about worker quality without committing to the binding rules of a formal employment contract. If the employer finds the worker unsatisfactory, she will not offer a formal employment contract, otherwise an employment relationship commences. Since employees enjoy better protection in formal employment contracts, e.g. with respect to layoff rules, and because salaries are frequently renegotiated after probation periods, workers have an incentive to cooperate with the employer during the probation period. Thus it is hypothesized that "bad" workers attempt to mimick "good" workers for this time in order to obtain a (better) continuation contract. The incentive for such mimicking behavior disappears as soon as the probation period terminates and the formal employment contract is signed. Within the German institutional framework probation periods typically last six months.

This study tests whether behaviors change after the end of the probation period at the example of absenteeism. It tests the hypothesis that absence probabilities increase after the end of probation periods, i.e. after the first six months of tenure. We investigate the full sample of employees in new employment situations and separately evaluate the behaviors of blue collar, white collar, and white collar public sector employees. In almost all cases we find large jumps in the predicted probability of a work absence after probation periods are completed. For the white collar and public sector employees, for whom the six months probation period applies most reliably (blue collar workers at times have only one or three months of probation), coefficient estimates confirm the hypothesis of behavioral adjustments after the sixth tenure month. For public sector employees the predicted probability of a work absence is significantly higher after the probation period is completed.

These results confirm the hypothesis of behavioral effects of probation periods and are robust to various changes in estimation methods. A limitation of the analysis lies in the small number of observations in each of the subsamples, another is the fact that we do now know with certainty whether workers indeed underwent probation periods of six months. Nevertheless, this is the first study to provide robust empirical foundations to a theoretical literature which so far had to assume behavioral adjustments in response to probation periods. 


\section{References}

Barmby, Tim A., Marco Ercolani, and John G. Treble, 1997, A Monthly Sickness Absence Series for Britain, 1971-1984, University of Essex - Institute for Labor Research Discussion Paper, No. 97 / 14.

Barmby, Tim and Gesine Stephan, 1996, Worker Absenteeism and Firm Size, Newcastle Discussion Papers in Economics Nr. 9601.

Barmby, Tim, Chris Orme, and John Treble, 1995, Worker Absence Histories: A Panel Data Study, Labour Economics 2, 53-65.

BMA (Bundesministerium für Arbeits- und Sozialordnung), 1995, Übersicht über das Sozialrecht, third edition, Bonn.

Bruse, Detlev (ed.), 1991, BAT-Kommentar für die Praxis, Bund Verlag, Köln.

Bull, Clive and PieroTedeschi, 1989, Optimal Probation for New Hires, Journal of Institutional and Theoretical Economics 145(4), 627-642.

Johansson, Per and Mårten Palme, 1996, Do Economic Incentives Affect Work Absence? Empirical Evidence Using Swedish Micro Data, Journal of Public Economics 59, 195-218.

Loh, Eng Seng, 1994a, The Determinants of Employment Probation Lengths, Industrial Relations 33(3), 386-406.

Loh, Eng Seng, 1994b, Employment Probation as a Sorting Mechanism, Industrial and Labor Relations Review 47(3), 471-486.

Sadanand, Asha, Vekatraman Sadanand, and Denton Marks, 1989, Probationary Contracts in Agencies with Bilateral Aymmetric Information, Canadian Journal of Economics 22(3), 643-661.

Schaub, Günther, 1997a, Meine Rechte und Pflichten als Arbeitnehmer, Deutscher Taschenbuchverlag, München.

Schaub, Günther, 1997b, Arbeitsrecht von A-Z, C.H. Beck Verlag. München.

Schnabel, Claus and Gesine Stephan, 1993, Determinanten des Krankenstandes: Eine Untersuchung mit Betriebs- und Zeitreihendaten, Jahrbuch Sozialwissenschaft 44, 132-147.

STBA (Statistisches Bundesamt), 1998, Statistical Yearbook 1998 for the Federal Republic of Germany, Metzler Poeschel, Wiesbaden.

Vistnes, Jessica P., 1997, Gender Differences in Days Lost from Work Due to Illness, Industrial and Labor Relations Review 50(2), 304-323.

Wang, Ruqu and Andrew Weiss, 1998, Probation, Layoffs, and Wage-Tenure Profiles: A Sorting Explanation, Labour Economics 5(3), 359-383.

Weiss, Andrew and Ruqu Wang, 1990, A Sorting Model of Labor Contracts: Implications for Layoffs and Wage-Tenure Profiles, NBER Working Paper No. 3448. 
Figure $1 \quad$ Stylized Absenteeism Probability by Tenure Months

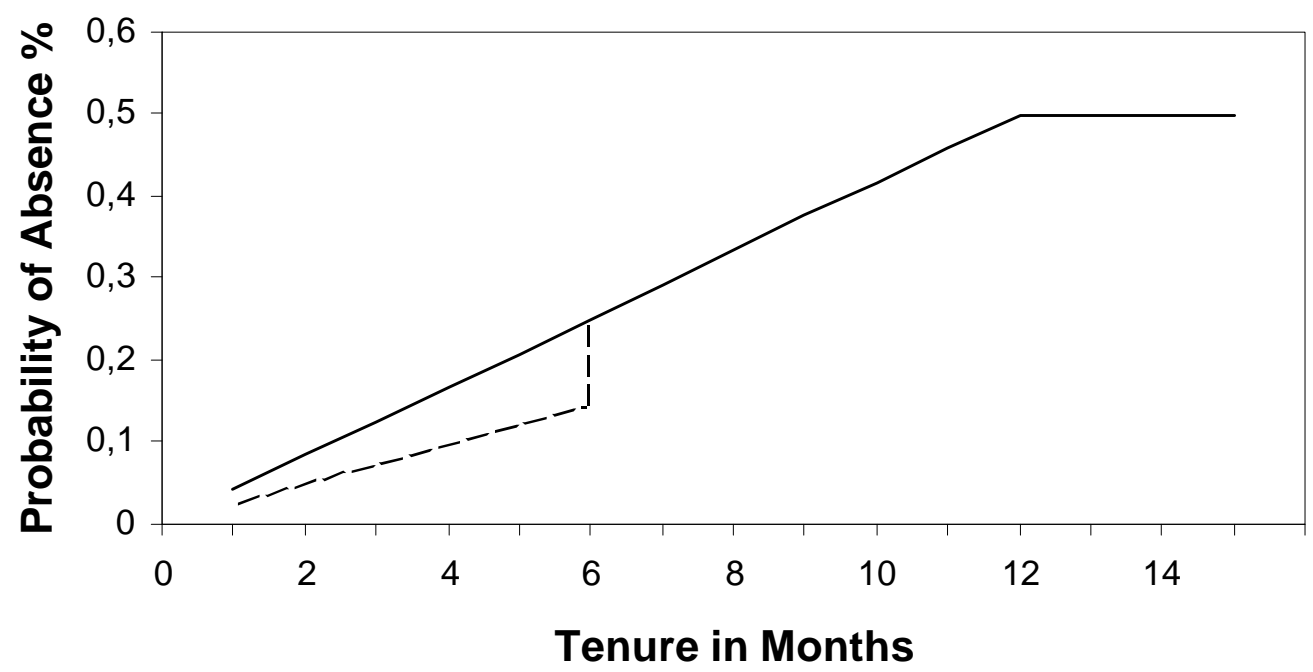

No Probation - - - - Probation

Figure 2 Seasonality of Health Related Work Absences

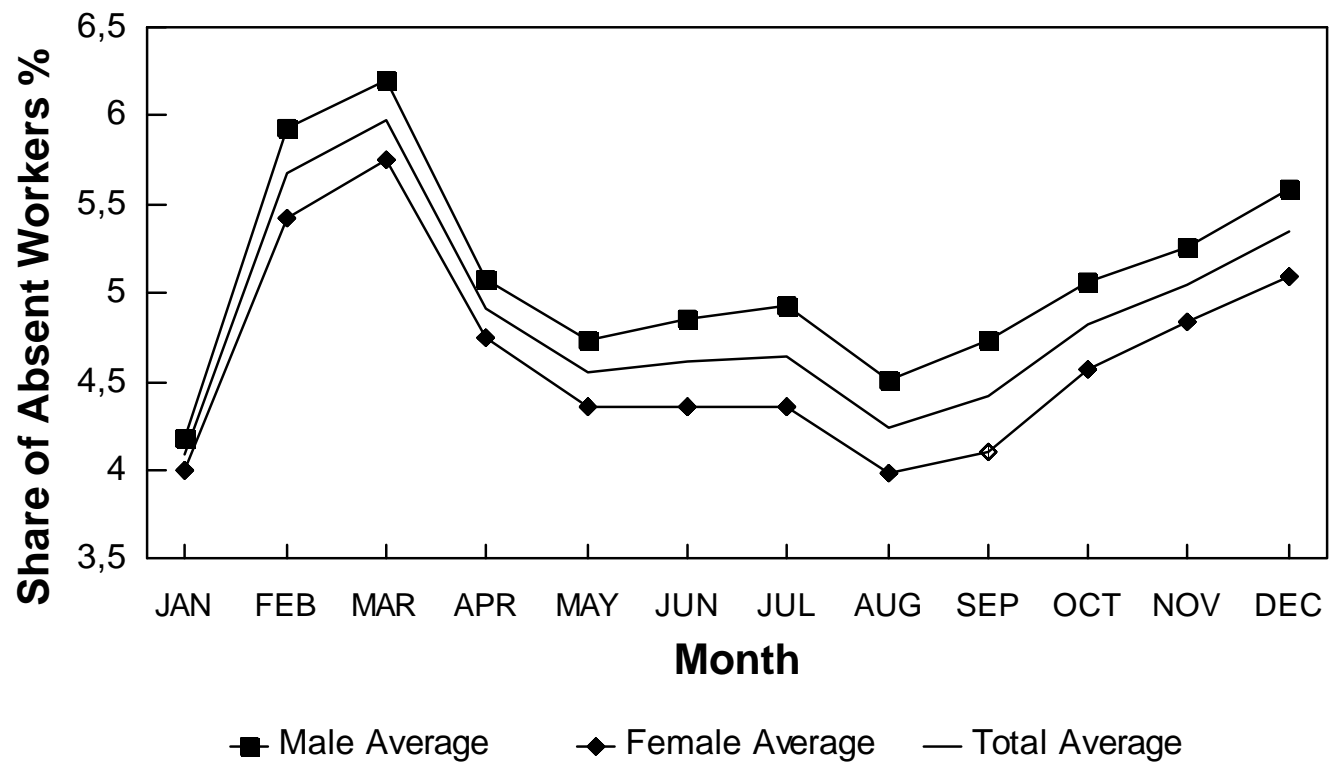

Note: $\quad$ Monthly averages calculated for 1983 through 1997: Number of workers on sickleave over all insured employees, at the first of the month.

Source: $\quad$ Federal Statistical Office: Time series service (segment 306). 
Figure 3 Simulated Absenteeism Probability by Tenure Months $3.1 \quad$ Full Sample

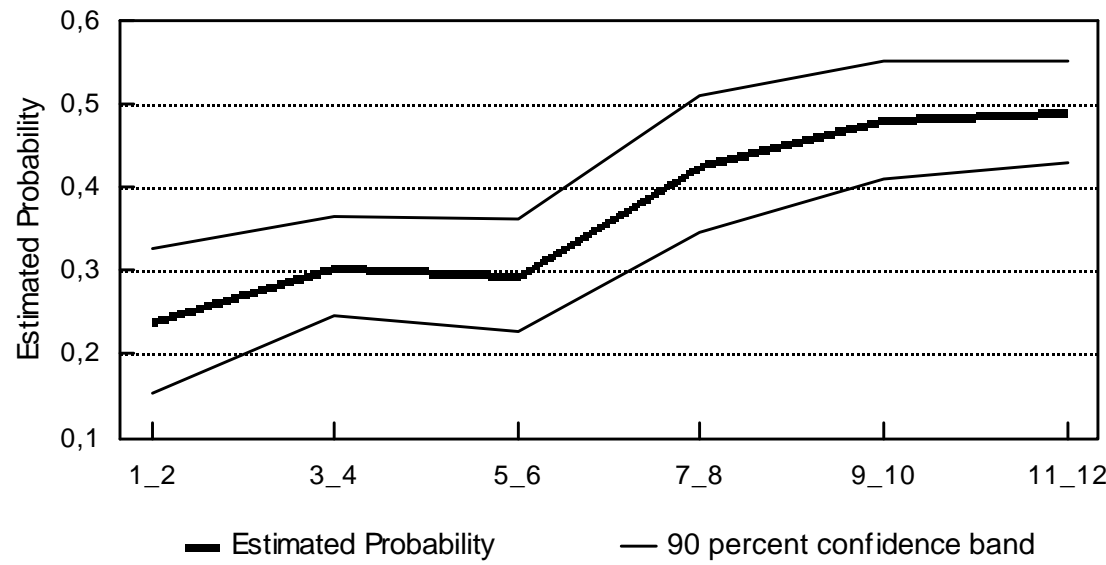

\subsection{Blue Collar Men}

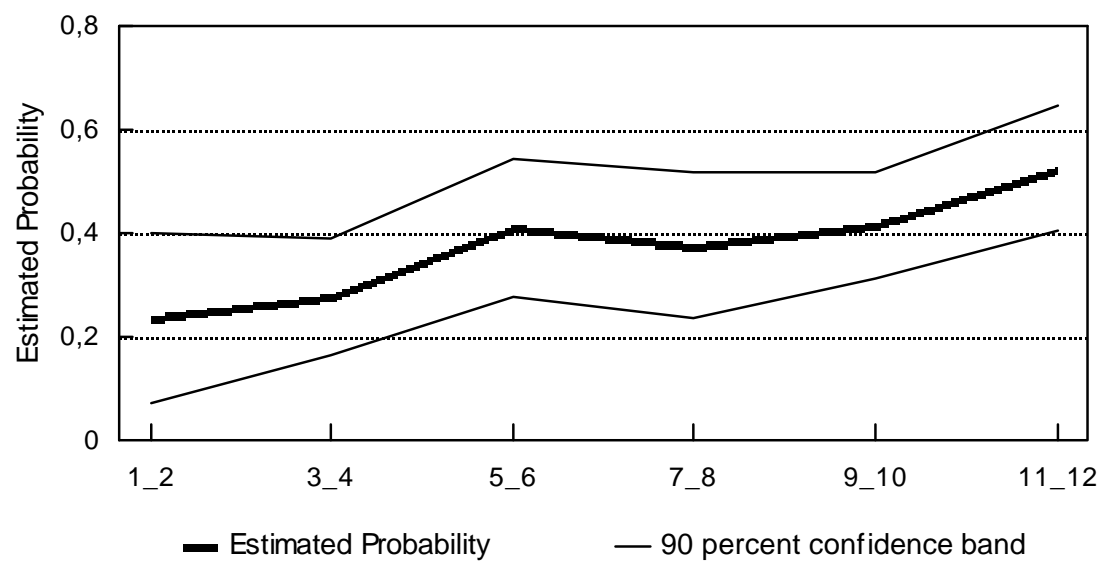

\subsection{Blue Collar Women}

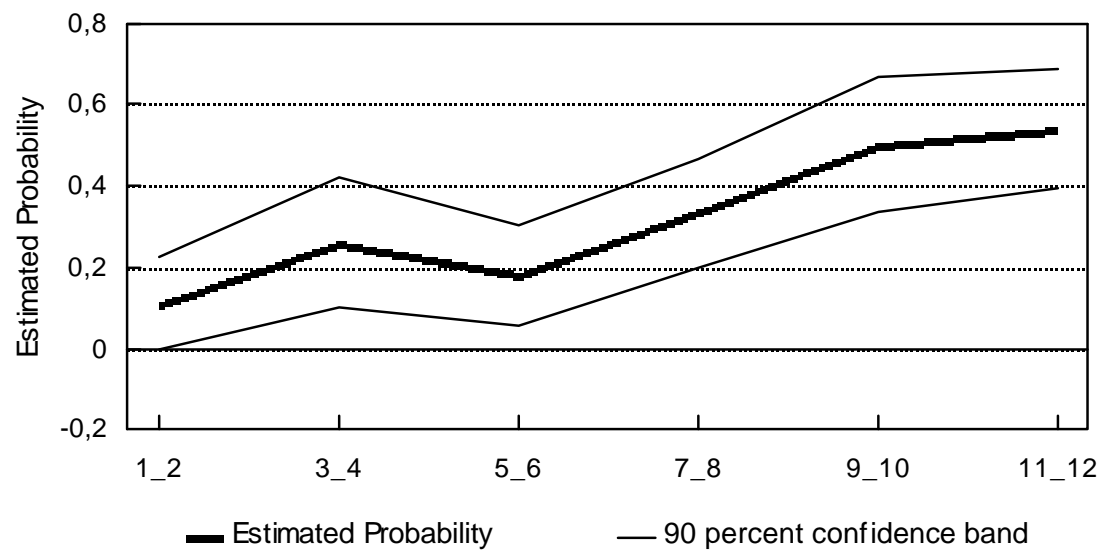




\subsection{White Collar Men}

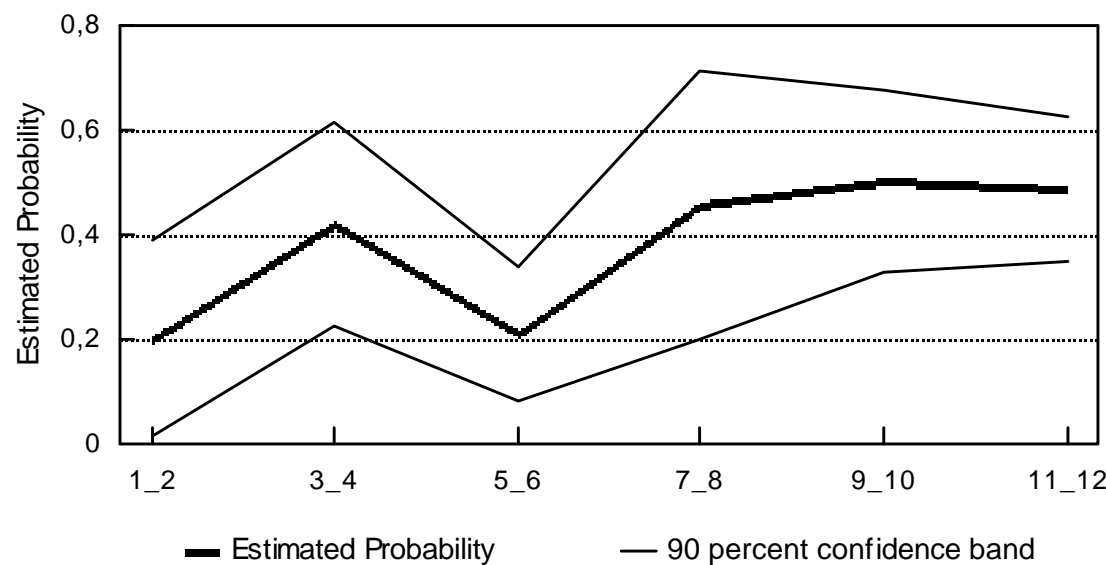

\subsection{White Collar Women}

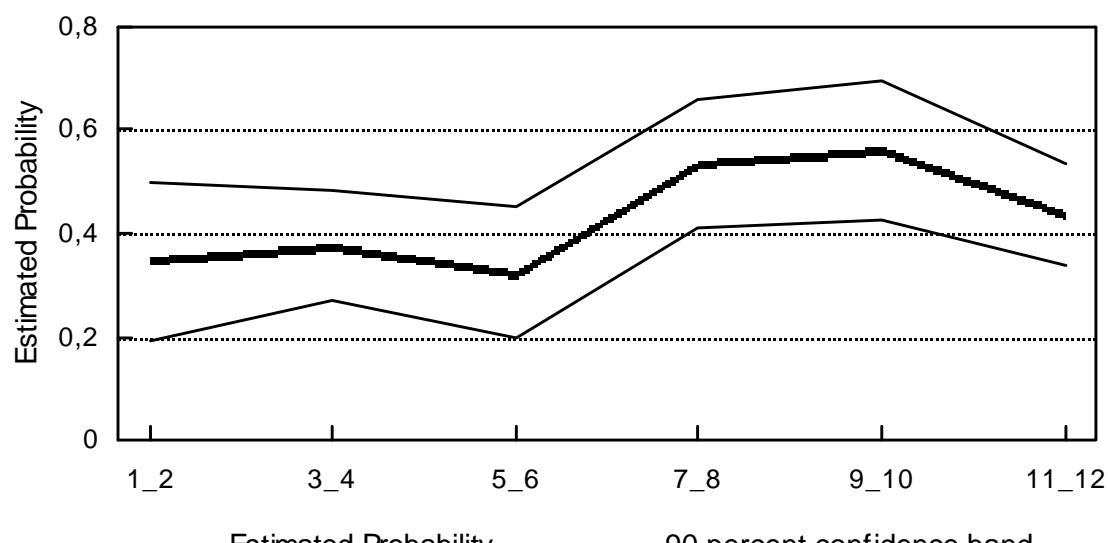

_ Estimated Probability

— 90 percent confidence band

\subsection{Public Sector}

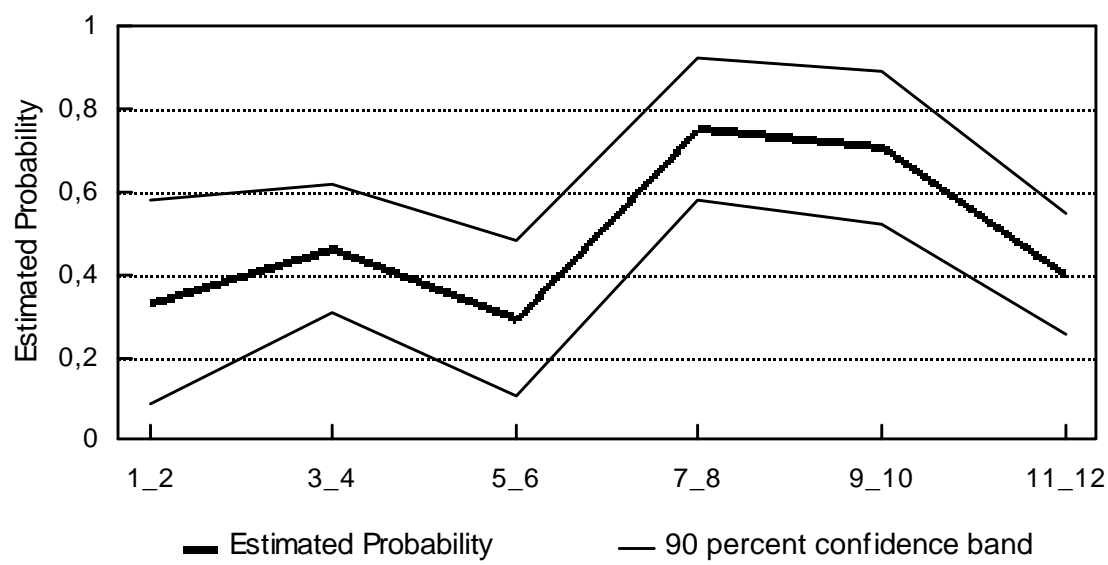


Figure 4 Simulation Results Across Analysis Steps

\subsection{White Collar Men}

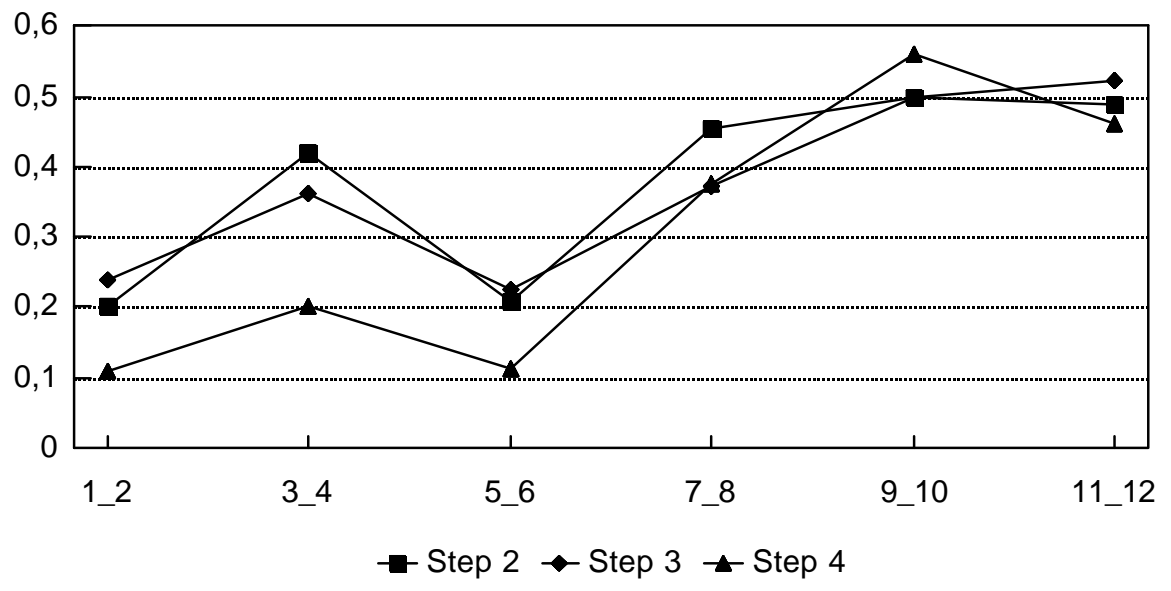

4.2 White Collar Females

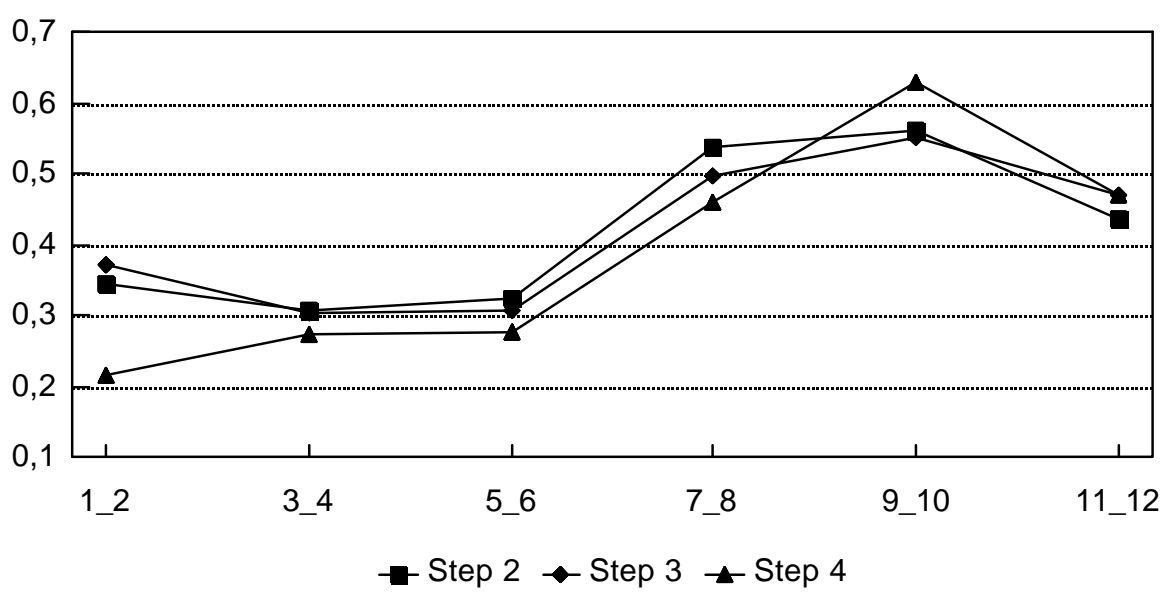

4.3 Public Sector

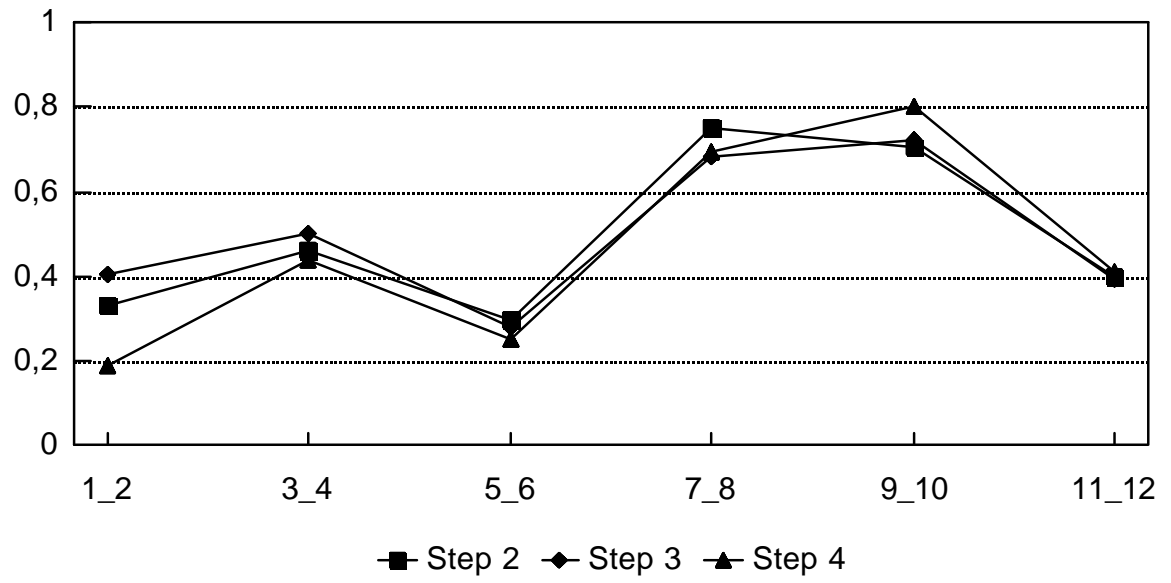


Table 1 Descriptive Statistics

\begin{tabular}{|c|c|c|c|}
\hline Variable & Definition & Mean & Std.D. \\
\hline ABSENT & 1 if individual has been absent, else 0 & 0.39 & 0.488 \\
\hline AGE $17-21$ & Individual aged 17 through 21 , else 0 & 0.218 & 0.413 \\
\hline AGE $22-24$ & Individual aged 22 through 24 , else 0 & 0.173 & 0.378 \\
\hline AGE $25-29$ & Individual aged 25 through 29 , else 0 & 0.215 & 0.411 \\
\hline AGE $30-39$ & Individual aged 30 through 39 , else 0 & 0.238 & 0.426 \\
\hline AGE $\$ 40$ & Individual aged at least 40 , else 0 & 0.156 & 0.364 \\
\hline MALE & Individual is male, else 0 & 0.461 & 0.499 \\
\hline FOREIGN & 1 if not of German nationality, else 0 & 0.313 & 0.464 \\
\hline MARRIED & 1 if married, else 0 & 0.469 & 0.499 \\
\hline HEALTHSAT & Health satisfaction coded 0 (low) to 10 (high) & 7.345 & 2.164 \\
\hline HANDICAP & 1 if individual is handicapped, else 0 & 0.043 & 0.202 \\
\hline PUBLIC SECTOR & 1 if employed in public sector, else 0 & 0.200 & 0.400 \\
\hline WORKTIME & Contracted weekly working hours & 34.53 & 9.079 \\
\hline WHITE COLLAR & 1 if white collar worker, else 0 & 0.488 & 0.500 \\
\hline BLUE COLLAR & 1 if blue collar worker, else 0 & 0.519 & 0.500 \\
\hline SMALL FIRM & 1 if employed in firm with less than 20 workers, else 0 & 0.294 & 0.456 \\
\hline UNEMPLOYMENT & State unemployment rate (in percent) & 8.436 & 2.524 \\
\hline SCHOOLING & Years of schooling & 11.019 & 2.987 \\
\hline TENURE $1 \& 2$ & 1 if tenure is 1 or 2 months, else 0 & 0.089 & 0.285 \\
\hline TENURE $3 \& 4$ & 1 if tenure is 3 or 4 months, else 0 & 0.176 & 0.381 \\
\hline TENURE 5 \& 6 & 1 if tenure is 5 of 6 months, else 0 & 0.170 & 0.376 \\
\hline TENURE $7 \& 8$ & 1 if tenure is 7 or 8 months, else 0 & 0.146 & 0.354 \\
\hline TENURE $9 \& 10$ & 1 if tenure is 9 or 10 months, else 0 & 0.190 & 0.393 \\
\hline TENURE $11 \& 12$ & 1 if tenure is 11 or 12 months, else 0 & 0.228 & 0.420 \\
\hline TENURE & Share of tenure months in first year $(1=$ full year $)$ & 0.604 & 0.282 \\
\hline PROBATION & 1 if tenure less than 6 months, else 0 & 0.436 & 0.496 \\
\hline PROBAT.* TENURE & Interaction term: Probation times months of tenure & 0.142 & 0.181 \\
\hline
\end{tabular}

Source: German Socioeconomic Panel, 799 observations (1984-1997). 
Table 2 Average Observed Probability of Absence by Tenure Months in First Employment Year (in percent)

\begin{tabular}{|c|c|c|c|c|c|c|c|c|c|c|c|c|c|c|c|c|}
\hline \multirow[b]{3}{*}{ TENURE $1 \& 2$} & \multirow{2}{*}{\multicolumn{2}{|c|}{ All }} & \multicolumn{6}{|c|}{ Blue Collar } & \multicolumn{6}{|c|}{ White Collar } & \multirow{2}{*}{\multicolumn{2}{|c|}{$\begin{array}{l}\text { White Collar } \\
\text { Public Sector }\end{array}$}} \\
\hline & & & \multicolumn{2}{|c|}{ All } & \multicolumn{2}{|c|}{ Men } & \multicolumn{2}{|c|}{ Women } & \multicolumn{2}{|c|}{ All } & \multicolumn{2}{|c|}{ Men } & \multicolumn{2}{|c|}{ Women } & & \\
\hline & 0.239 & 71 & 0.171 & 35 & 0.235 & 17 & 0.111 & 18 & 0.306 & 36 & 0.200 & 10 & 0.346 & 26 & 0.333 & 9 \\
\hline TENURE 3 \& 4 & 0.305 & 141 & 0.271 & 70 & 0.277 & 47 & 0.261 & 23 & 0.338 & 71 & 0.421 & 19 & 0.308 & 52 & 0.462 & 26 \\
\hline TENURE 5 \& 6 & 0.294 & 136 & 0.313 & 67 & 0.410 & 39 & 0.179 & 28 & 0.275 & 69 & 0.207 & 29 & 0.325 & 40 & 0.294 & 17 \\
\hline TENURE $7 \& 8$ & 0.427 & 117 & 0.354 & 65 & 0.375 & 32 & 0.333 & 33 & 0.519 & 52 & 0.455 & 11 & 0.537 & 41 & 0.750 & 20 \\
\hline TENURE 9 \& 10 & 0.480 & 152 & 0.440 & 91 & 0.413 & 63 & 0.500 & 28 & 0.541 & 61 & 0.500 & 20 & 0.561 & 41 & 0.706 & 17 \\
\hline TENURE $11 \& 12$ & 0.489 & 182 & 0.531 & 81 & 0.523 & 44 & 0.541 & 37 & 0.455 & 101 & 0.486 & 37 & 0.438 & 64 & 0.400 & 30 \\
\hline Total & 0.391 & 799 & 0.372 & 409 & 0.389 & 242 & 0.347 & 167 & 0.410 & 390 & 0.389 & 126 & 0.421 & 264 & 0.496 & 119 \\
\hline
\end{tabular}

Note: In each cell the first figure provides the average probability of absence and the second figure gives the number of observations. 
Table 3 Estimation and Simulation Results: Only Controlling for Tenure Effects

\begin{tabular}{|c|c|c|c|c|c|c|c|c|c|c|c|c|c|c|}
\hline & \multirow{2}{*}{\multicolumn{2}{|c|}{$\begin{array}{c}\text { Full Sample } \\
\text { (1) }\end{array}$}} & \multirow{2}{*}{\multicolumn{2}{|c|}{ Full Sample }} & \multicolumn{4}{|c|}{ Blue Collar } & \multicolumn{4}{|c|}{ White Collar } & \multirow{2}{*}{\multicolumn{2}{|c|}{$\begin{array}{c}\text { White Collar } \\
\text { Public Sector } \\
(7)\end{array}$}} \\
\hline & & & & & \multicolumn{2}{|c|}{$\begin{array}{c}\text { Men } \\
(3)\end{array}$} & \multicolumn{2}{|c|}{$\begin{array}{c}\text { Women } \\
(4) \\
\end{array}$} & \multicolumn{2}{|c|}{$\begin{array}{c}\text { Men } \\
(5) \\
\end{array}$} & \multicolumn{2}{|c|}{$\begin{array}{c}\text { Women } \\
(6)\end{array}$} & & \\
\hline \multicolumn{15}{|c|}{ Estimation Results } \\
\hline tenure & 0.274 & $(0.68)$ & - & - & - & - & - & - & - & - & - & - & - & - \\
\hline probation & -0.578 & $(1.47)$ & - & - & - & - & - & - & - & - & - & - & - & - \\
\hline prob. $*$ tenure & 0.687 & $(0.98)$ & - & - & - & - & - & - & - & - & - & - & - & - \\
\hline tenure $1 \& 2$ & - & - & -0.681 & $* *(3.62)$ & -0.779 & $*(2.02)$ & -0.132 & $* *(2.98)$ & -0.808 & $(1.62)$ & -0.238 & $(0.80)$ & -0.177 & $(0.36)$ \\
\hline tenure $3 \& 4$ & - & - & -0.483 & $* *(3.34)$ & -0.650 & $* *(2.39)$ & -0.743 & $*(2.12)$ & -0.165 & $(0.46)$ & -0.345 & $(1.43)$ & 0.157 & $(0.46)$ \\
\hline tenure $5 \& 6$ & - & - & -0.514 & $* *(3.50)$ & -0.284 & (1.02) & -1.023 & $* *(2.95)$ & -0.783 & $* *(2.33)$ & -0.296 & $(1.14)$ & -0.288 & $(0.73)$ \\
\hline tenure $7 \& 8$ & - & - & -0.156 & (1.04) & -0.376 & $(1.27)$ & -0.533 & $\mathrm{R}(1.74)$ & -0.080 & (0.19) & 0.249 & $(0.99)$ & 0.928 & $*(2.41)$ \\
\hline tenure $9 \& 10$ & - & - & -0.022 & $(0.16)$ & -0.278 & $(1.12)$ & -0.102 & $(0.32)$ & 0.034 & $(0.10)$ & 0.311 & $(1.23)$ & 0.795 & $*(2.00)$ \\
\hline constant & 0.299 & $(0.90)$ & -0.028 & $(0.30)$ & 0.570 & $(0.30)$ & 0.102 & $(0.49)$ & -0.034 & $(0.16)$ & -0.157 & $(0.99)$ & -0.253 & $(1.09)$ \\
\hline $\mathrm{N}$ & \multicolumn{2}{|c|}{799} & \multicolumn{2}{|c|}{799} & \multicolumn{2}{|c|}{242} & \multicolumn{2}{|c|}{167} & \multicolumn{2}{|c|}{126} & \multicolumn{2}{|c|}{264} & \multicolumn{2}{|c|}{119} \\
\hline Log Likelihood & \multicolumn{2}{|c|}{-518.887} & \multicolumn{2}{|c|}{-519.393} & \multicolumn{2}{|c|}{-157.719} & \multicolumn{2}{|c|}{-98.56} & \multicolumn{2}{|c|}{-79.8} & \multicolumn{2}{|c|}{-174.37} & \multicolumn{2}{|c|}{-75.71} \\
\hline LRT Tenure & \multicolumn{2}{|c|}{$31.23 * *$} & \multicolumn{2}{|c|}{$29.67 * *$} & \multicolumn{2}{|c|}{7.7} & \multicolumn{2}{|c|}{$17.23 * *$} & \multicolumn{2}{|c|}{8.32} & \multicolumn{2}{|c|}{$10.36 *$} & \multicolumn{2}{|c|}{$12.81 *$} \\
\hline Simulation Resul & & & & & & & & & & & & & & \\
\hline tenure $1 \& 2$ & 0.224 & $(5.63)$ & 0.239 & $(4.58)$ & 0.235 & $(2.36)$ & 0.111 & $(1.62)$ & 0.200 & $(1.75)$ & 0.346 & (3.68) & 0.333 & $(2.26)$ \\
\hline tenure $3 \& 4$ & 0.275 & $(11.1)$ & 0.305 & $(8.50)$ & 0.277 & $(4.03)$ & 0.261 & $(2.71)$ & 0.421 & $(3.55)$ & 0.308 & (5.79) & 0.462 & $(4.82)$ \\
\hline tenure $5 \& 6$ & 0.331 & $(8.74)$ & 0.294 & $(7.16)$ & 0.410 & $(5.08)$ & 0.179 & $(2.38)$ & 0.207 & $(2.68)$ & 0.325 & (4.29) & 0.294 & $(2.58)$ \\
\hline tenure $7 \& 8$ & 0.449 & (11.05) & 0.427 & $(8.53)$ & 0.375 & $(4.40)$ & 0.333 & $(4.06)$ & 0.455 & $(2.91)$ & 0.537 & $(7.08)$ & 0.750 & (7.19) \\
\hline tenure $9 \& 10$ & 0.447 & $(8.86)$ & 0.480 & (11.11) & 0.413 & $(6.59)$ & 0.500 & $(4.92)$ & 0.500 & $(4.74)$ & 0.561 & (6.88) & 0.706 & $(6.28)$ \\
\hline tenure $11 \& 12$ & 0.485 & $(14.55)$ & 0.489 & (13.24) & 0.523 & $(7.21)$ & 0.541 & (6.19) & 0.487 & $(5.72)$ & 0.438 & $(7.22)$ & 0.400 & (4.57) \\
\hline
\end{tabular}

Notes: In parentheses White-corrected absolute t-values. **, $*$ and Rindicate statistical significance at the 1,5 , and 10 percent level, respectively. LRT Tenure presents the $\div^{2}$ test statistic and significance for the joint test of all tenure coefficients.

Standard errors of simulation results generated by bootstrap (500 repetitions). 
Table 4 Estimation Results: Explanatory Variables in Full Sample Without and With Controls for Unobserved Heterogeneity

\begin{tabular}{|c|c|c|c|c|}
\hline \multirow[t]{2}{*}{ Variable } & \multicolumn{2}{|c|}{ Step 3} & \multicolumn{2}{|c|}{ Step 4} \\
\hline & Coeff . & $\begin{array}{l}\text { ymptotic } \\
\text {-Value }\end{array}$ & Coeff . & $\begin{array}{c}\text { Asymptotic } \\
\text { T-Value }\end{array}$ \\
\hline \multicolumn{5}{|l|}{ Demographic Variables } \\
\hline Age $17-21$ & $0.557^{* *}$ & 2.917 & $0.357^{* *}$ & 5.422 \\
\hline Age $22-24$ & $0.544 * *$ & 2.991 & $0.301 * *$ & 6.067 \\
\hline Age $25-29$ & $0.351 *$ & 2.084 & $0.388^{* *}$ & 10.206 \\
\hline Age $30-39$ & $0.331 *$ & 2.086 & $0.158 * *$ & 5.562 \\
\hline Male & -0.084 & -0.780 & $-0.254 * *$ & -8.134 \\
\hline Foreign & $-0.269^{*}$ & -2.370 & $0.058 \mathrm{R}$ & 1.771 \\
\hline Married & -0.057 & -0.470 & 0.014 & 0.480 \\
\hline \multicolumn{5}{|l|}{ Health Status } \\
\hline Health Satisfaction & $-0.060^{* *}$ & -2.560 & $-0.099 * *$ & -19.63 \\
\hline Handicap & $0.491^{*}$ & 2.009 & $0.368^{* *}$ & 7.580 \\
\hline \multicolumn{5}{|l|}{ Employment Relation } \\
\hline Public Sector & 0.179 & 1.458 & $0.151^{* *}$ & 4.641 \\
\hline Worktime & $0.012 R$ & 1.949 & $0.011^{* *}$ & 5.855 \\
\hline White Collar & 0.074 & 0.618 & $-0.163^{* *}$ & -5.401 \\
\hline Small Firm & -0.053 & -0.500 & $-0.222 * *$ & -7.410 \\
\hline Years of Schooling & -0.004 & -0.240 & 0.001 & 0.219 \\
\hline State Unemployment & $-0.065^{* *}$ & -3.470 & $-0.029 * *$ & -6.243 \\
\hline \multicolumn{5}{|l|}{ Tenure Indicators } \\
\hline Tenure $1 \& 2$ & $-0.719^{* *}$ & -3.790 & $-1.451 * *$ & -7.355 \\
\hline Tenure $3 \& 4$ & $-0.546^{* *}$ & -3.600 & $-1.120^{* *}$ & -8.294 \\
\hline Tenure $5 \& 6$ & $-0.605^{* *}$ & -3.980 & $-1.042 * *$ & -7.772 \\
\hline Tenure $7 \& 8$ & -0.227 & -1.470 & $-0.836^{* *}$ & -5.884 \\
\hline Tenure $9 \& 10$ & -0.033 & -0.230 & $-0.306^{*}$ & -2.444 \\
\hline Tenure $11 \& 12$ & - & - & $-0.384 * *$ & -3.361 \\
\hline Tenure & - & - & 0.001 & 0.224 \\
\hline Tenure $^{\wedge} 2 / 100$ & - & - & -0.016 & -1.417 \\
\hline Constant & 0.333 & 0.868 & $0.894^{* * *}$ & 7.625 \\
\hline Rho & - & - & $0.382^{* *}$ & 38.824 \\
\hline Number of observations & 799 & & 30,028 & \\
\hline Log Likelihood & -492.90 & & -18150.63 & \\
\hline LRT Age & $10.57 *$ & & $106.23 * *$ & \\
\hline LRT Tenure & $34.05 * *$ & & $214.03 * *$ & \\
\hline
\end{tabular}

Note: $\quad \mathrm{T}$ values for Step 3 based on White-corrected standard errors. **, * and Rindicate statistical significance at the 1,5, and 10 percent level, respectively. LRT Age and LRT Tenure present the $\div^{2}$ test statistic and significance for the joint test of all age and tenure coefficients, respectively. 
Table 5 Estimation and Simulation Results: Controlling for Explanatory Variables and Tenure Effects

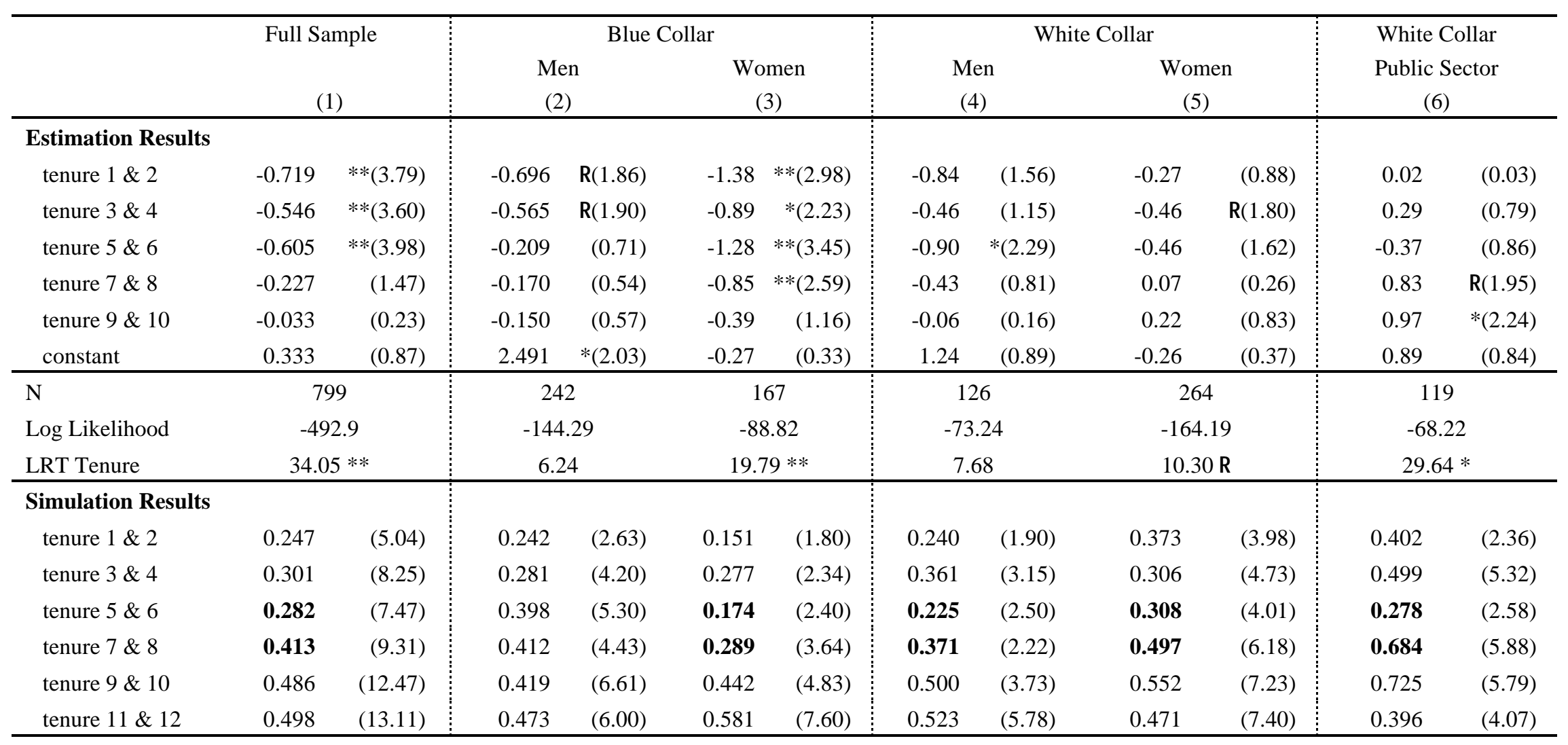

Notes: Coefficients of jointly estimated explanatory variables are not presented, the specifications follow the one presented in Table 4.

In parentheses White-corrected absolute t-values. **, * and Rindicate statistical significance at the 1, 5, and 10 percent level, respectively.

LRT Tenure presents the $\div^{2}$ test statistic and significance for the joint test of all tenure coefficients.

Standard errors of simulation results generated by bootstrap (500 repetitions). 
Table 6 Estimation and Simulation Results: Controlling for Explanatory Variables, Unobserved Heterogeneity and Tenure Effects

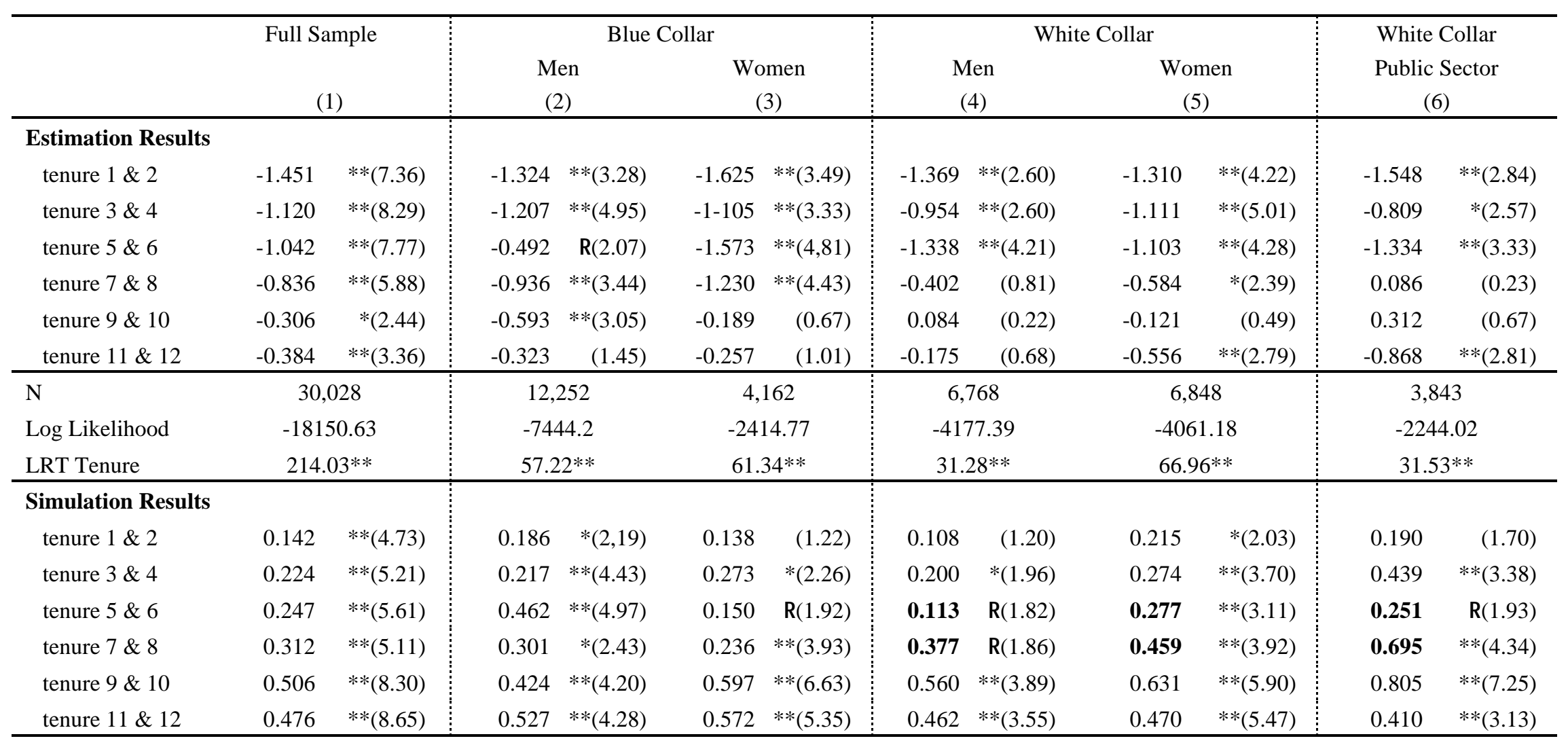

Notes: Coefficients of jointly estimated explanatory variables are not presented, the specifications follow the one presented in Table 4.

In parentheses absolute t-values. ${ }^{* *}, *$ and Rindicate statistical significance at the 1,5 , and 10 percent level, respectively.

The LRT-Tenure test statistics refer to the joint statistical significance of the effects of the six indicators for tenure of less than one year.

Standard errors of simulation results generated by bootstrap (50 repetitions). 